Article

\title{
Urban Regions Shifting to Circular Economy: Understanding Challenges for New Ways of Governance
}

\author{
Andreas Obersteg ${ }^{1, *}$, Alessandro Arlati ${ }^{1}$, Arianne Acke ${ }^{2}$, Gilda Berruti ${ }^{3}$, Konrad Czapiewski ${ }^{4}$, \\ Marcin Dąbrowski ${ }^{5}$, Erwin Heurkens ${ }^{5}$, Cecília Mezei ${ }^{6}$, Maria Federica Palestino ${ }^{3}$, Viktor Varjú ${ }^{6}$, \\ Marcin Wójcik ${ }^{7}$ and Jörg Knieling ${ }^{1}$ \\ ${ }^{1}$ HafenCity, University Hamburg, 20457 Hamburg, Germany; E-Mails: andreas.obersteg@hcu-hamburg.de (A.O.), \\ alessandro.arlati@hcu-hamburg.de (A.A.), joerg.knieling@hcu-hamburg.de (J.K.) \\ 2 OVAM-Public Waste Agency of Flanders, 2800 Mechelen, Belgium; E-Mail: aacke@ovam.be \\ ${ }^{3}$ Department of Architecture, University of Naples Federico II, 80134 Naples, Italy; E-Mails: gberruti@unina.it (G.B), \\ palestin@unina.it (M.F.P.) \\ ${ }^{4}$ IGPZ PAN-Institute of Geography and Spatial Organization, 00-818 Warszawa, Poland; E-Mail: konrad@twarda.pan.pl \\ ${ }^{5}$ Departments of Urbanism and Management in the Built Environment, Faculty of Architecture and the Built Environment, \\ TU Delft, 2628 Delft, The Netherlands; E-Mails: m.m.dabrowski@tudelft.nl (M.D.) e.w.t.m.heurkens@tudelft.nl (E.H.) \\ ${ }^{6}$ MTA KRTK — Institute for Regional Studies, 7621 Pécs, Hungary; E-Mails: mezeic@rkk.hu (C.M.), varju@rkk.hu (V.V.) \\ ${ }^{7}$ Faculty of Geographical Sciences, University of Łódź, 31 Kopcińskiego, Poland; E-Mail: marcin.wojcik@geo.uni.lodz.pl \\ * Corresponding author
}

Submitted: 31 March 2019 | Accepted: 10 July 2019 | Published: 27 September 2019

\begin{abstract}
Urban areas account for around $50 \%$ of global solid waste generation. In the last decade, the European Union has supported numerous initiatives aiming at reducing waste generation by promoting shifts towards Circular Economy (CE) approaches. Governing this process has become imperative. This article focuses on the results of a governance analysis of six urban regions in Europe involved in the Horizon 2020 project REPAiR. By means of semi-structured interviews, document analysis and workshops with local stakeholders, for each urban area a list of governance challenges which hinder the necessary shift to circularity was drafted. In order to compare the six cases, the various challenges have been categorized using the PESTEL-O method. Results highlight a significant variation in policy contexts and the need for these to evolve by adapting stakeholders' and policy-makers' engagement and diffusing knowledge on CE. Common challenges among the six regions include a lack of an integrated guiding framework (both political and legal), limited awareness among citizens, and technological barriers. All these elements call for a multi-faceted governance approach able to embrace the complexity of the process and comprehensively address the various challenges to completing the shift towards circularity in cities.
\end{abstract}

\section{Keywords}

challenges; circular economy; governance; peri-urban areas; urban region

Issue

This article is part of the issue "Facilitating Circular Economy in Urban Planning", edited by Hilde Remoy (Delft University of Technology, The Netherlands), Alexander Wandl (Delft University of Technology, The Netherlands) and Denis Ceric (Polish Academy of Sciences, Poland).

(C) 2019 by the authors; licensee Cogitatio (Lisbon, Portugal). This article is licensed under a Creative Commons Attribution 4.0 International License (CC BY).

\section{Introduction}

The need for a shift to a more sustainable way of living is key in recent strategies at European level (European
Union [EU], 2017). In order to reach this goal in a comprehensive manner, the process needs to be carefully governed. At this point, several problems and challenges have emerged, due to the relative novelty and complex- 
ity of Circular Economy (CE) as a policy field; furthermore, there are still only few studies on governance of $\mathrm{CE}$, particularly at the scale of urban regions (Section 2); and thus requiring a solid methodology (Section 3 ).

It is argued that an analysis of governance settings and related challenges is necessary to delineate new ways of governance towards circularity. The latter should allow cross-cutting (horizontal) and multi-level (vertical) involvement of various actors in finding answers to challenges posed by $\mathrm{CE}$.

This article attempts to address this knowledge gap by providing guidelines for overcoming barriers and taking advantage of opportunities within governance settings to develop CE thinking on the level of urban regions. These have been developed through an explorative analysis (Section 4) of the first results on governance challenges for CE in six European peri-urban areas, as an output of the ongoing Horizon2020 Project REPAiR. The challenges derived from the six cases are compared, analyzed and discussed in Section 5. Thus, gaps in the current literature on governance of $\mathrm{CE}$ in urban regions are addressed. Furthermore, an account is provided on how, at regional scale, stakeholders from different governance fields and levels grapple with those issues.

We argue that the challenges linked to the different and context-specific governance and institutional settings have a significant impact on the effectiveness of resource management processes in observance of the EU goals for CE (Section 6).

\section{The Need for Governance Change in Urban Regions}

Urban areas are responsible for around $50 \%$ of global solid waste generation and between $60 \%$ and $80 \%$ of greenhouse gas production (Camaren \& Swilling, 2012; Chávez et al., 2018). Facing ongoing urbanization, it is also predicted that consumption of goods and services and, as a consequence, the use of resources in cities, will grow in the future (McKinsey Global Institute, 2016).

Over the last decades, various concepts with regard to resource consumption and flows of materials have been developed and discussed. The urban metabolism concept as one of the most comprehensive approaches was first outlined by Wolman in 1965. It aims at understanding the flows into and out of cities and has been adapted several times, with recent approaches trying to further integrate social and economic aspects and to develop proposals on how to (re-)build cities in a more circular way (Kennedy, Pincetl, \& Bunje, 2011).

While urban metabolism focused on cities, the concept of CE was conceived as primarily non-spatial as its focus is on the reorganization of enterprises, sectors and the economy. The objective is to close resource loops by recycling waste and reusing materials (Ghisellini, Cialani, \& Ulgiati, 2016). The CE approach has been translated into policy recommendations by-among others-the Ellen MacArthur Foundation (2013). Also, building on the CE concept, the EU has adopted strategies-e.g., the
Circular Economy Strategy 2017-to make Europe's economy more circular (EU, 2017).

An important step when approaching CE-oriented actions is to determine their setting and the boundaries of their impact. Among the extensive recent literature on the city scale of CE is a suggested approach able to provide a holistic interpretation, allowing a systematic view of problems and objectives (Geng \& Doberstein, 2008; Ghisellini et al., 2016). This is said to help in integrating the local/territorial approach, since the main flows of materials are organized in very different ways based on variations in local conditions (European Spatial Planning Observation Network, 2019).

Girardet (2015) attempted to connect the concept of CE with urban development approaches in his regenerative city concept; while Williams (2019) emphasized the deficits of the CE concept with regard to spatial and social questions. Both authors accentuate the necessity of effective governance in the process of applying CE ideas to cities. For sustaining and facilitating such changes, a territorial governance approach which integrates the multi-level and cross-sectoral features of governance must be considered (Schmitt \& Van Well, 2016; Van Well \& Schmitt, 2016).

Recent studies have examined circular city and CE strategies on the municipal level. Prendeville, Cherim and Bocken (2018) discuss the concept of circular cities by analyzing circular city strategies and their implementation in six cases. They argue that, even though policymakers are interested in circular city strategies to achieve $\mathrm{CE}$ in cities, the implementation of these strategies faces limits: policymakers often rely on big economic stakeholders to execute $\mathrm{CE}$ in cities, while the development and implementation of these strategies lack an involvement of a broader stakeholder setting. Based on an analysis of CE strategies on the municipal level in 83 cities, Petit-Boix and Leipold (2018) recommend taking into account urban planning in the analysis of CE in cities as it influences many strategies linked to CE. Furthermore, they suggest involving key stakeholders in cities to identify barriers to and opportunities for the implementation of CE strategies.

In this article we consider the aforementioned demand for a better understanding of how CE could be achieved in cities and how CE and circular city approaches could be supported by key stakeholders. While the approaches of the studies of Petit-Boix and Leipold (2018) and Prendeville et al. (2018) focus on cities, we argue in this research that looking at urban regions is the more suitable scale to act for the concretization and spatialization of CE actions (Milligan \& O'Keeffe, 2019). Urban regions and especially their peri-urban areas are characterised by a patchwork of dispersed urbanized areas, agricultural land and open spaces. The Directorate General for Regional Policy of the European Commission underlined in Cities of Tomorrow: Challenges, Visions, Ways Forward (European Commission, Directorate General for Regional Policy [EC], 
2011) the presence of problems such as excessive use of resources and waste production, as well as urban sprawl and extensive land consumption in peri-urban parts of urban regions. This situation is often accompanied by fragmented local governments and planning systems. Nevertheless, while urban regions and notably their peri-urban areas are considered particularly relevant as a source of problems, their spatial configurations offer at the same time a range of possibilities to establish a CE and support sustainable development (EC, 2011; Knieling, Jacuniak-Suda, \& Obersteg, 2017).

Looking into the research on climate change and transition, different aspects and issues have been identified to categorize governance processes and challenges (Dewulf, Meijerink, \& Runhaar, 2015; Ehnert et al., 2018). Three main dimensions to examine governance challenges can be derived from this research:

(1) Multi-level governance considers the different scales that are involved in governance processes related to the shift of urban regions to CE (from local, regional, national to supranational) and the interactions between these levels;

(2) Cross-sectoral governance considers the involvement of different divisions of the public sector that are connected to circularity, such as waste management, spatial planning, environmental planning and business development;

(3) Multi-actor or quadruple helix governance focuses on the participation actors from public, private (enterprises), science (research institutions) and civil society (NGOs, initiatives) sectors.

These three dimensions were applied in our analysis with the aim to explore and enhance the understanding of the concrete governance challenges in nudging metropolitan urban regions towards a CE approach. A special focus in our research is set on identifying governance challenges where CE is linked to spatial affairs and planning. The research was conducted in six European case studies in the urban regions of Amsterdam, Naples, Ghent, Pécs, Łódź and Hamburg, using the methodology explained in Section three.

\section{Methodology}

Due to the novelty of the CE topic (Ghisellini et al., 2016), we opted for an exploratory approach describing six selected case studies around Europe to investigate the theoretical aspects derived from an extensive literature research in a real-world context (Yin, 1984/2009). Existing literature has drawn attention to implementation challenges of CE tenets at different levels (Franco, 2017; PetitBoix \& Leipold, 2018; Prendeville et al., 2018). We aim to enrich this discussion by highlighting the cross-cuttingmulti-level, multi-sectorial, multi-actors-nature of the implementation of CE actions and their spatial relationships (REPAiR, 2017e). The case study selection was driven by the necessity of identifying common elements in situations characterized by apparent profound social, economic and environmental diversities. Yet it was still following a comparability logic (Kaarbo \& Beasley, 1999); exploring the phenomena in all dimensions (Bartlett \& Vavrus, 2017). The number of cases was intentionally kept small, allowing "thick description" and adequate analytic depth (Collier, 1993, p. 109; Kaarbo \& Beasley, 1999).

Therefore, we primarily constructed a story for each case based on a total of 58 semi-structured interviews and archival sources such as published official documents and media reports. The interviews were conducted in loco with key stakeholders from waste management sector, local and regional authorities, housing companies, and representatives of the private sector (Nilsson, Eklund, \& Tyskeng, 2009, pp. 5-6) and using a snowball sampling method which led to the identification of additional stakeholders concerned with the CE topic in the six urban regions (snowball sampling; see Reed et al., 2009). The thus identified stakeholder constellation was considered for direct involvement in several meetings where challenges were addressed and discussed, following the Living Lab format (Advanced Metropolitan Solutions, 2017; REPAiR, 2017c). At least one organizer of these meetings per case study is author of the present article. The challenges produced in these meetings are summarized in Tables 2 to 8 .

To allow and facilitate comparison between the case studies, the analytical framework PESTEL (Political, Economic, Social, Technological, Environmental, and Legal) was used. First conceived as a tool for evaluating alternatives within organizations (e.g., Fozer et al., 2017; Song, Sun, \& Jin, 2017), the framework has proved to be of significant importance in the field of strategic planning due to its ability to provide a comprehensive overview on different factors, the challenges in our case (Osborne \& Brown, 2005; Yüksel, 2012), and simultaneously to highlight possible interdependencies between those (Codagnone \& Wimmer, 2007; Mietzner \& Reger, 2005). As governance is the focus of the present article, we considered it necessary to add organizational-related challenges as a seventh category for comparison sake.

\section{Governance Settings in the Six Urban Areas}

This section presents the governance background concerning spatial planning and CE topics in the case areas and provides an insight on the various challenges that a shift to CE requires. Table 1 shows key information for each case, followed by a more detailed description of each case.

\subsection{Amsterdam}

The Netherlands ranks among the top countries in the EU in terms of waste management (BiPRO, 2012), and has far-going ambitions to develop the country's econ- 
Table 1. Overview of the six focus areas in REPAiR project. Focus area indicates arbitrarily predetermined zones which contain peri-urban features.

\begin{tabular}{|c|c|c|}
\hline Case Study Focus Area & Inhabitants in the Focus Area (number) & Waste Stream Focus \\
\hline $\begin{array}{l}\text { Amsterdam-The Netherlands } \\
\text { (several municipalities in Amsterdam } \\
\text { Metropolitan Area including Aalsmeer, } \\
\text { Haarlemmermeer, Velsen, Zaanstad) }\end{array}$ & 758845 (2017) & $\begin{array}{l}\text { - Organic waste (OW) } \\
\text { - Construction \& demolition } \\
\text { waste (C\&D) } \\
\text { - Wastescapes }\end{array}$ \\
\hline $\begin{array}{l}\text { Naples-Italy } \\
\text { (Napoli Est, Casoria, Afragola, Acerra, } \\
\text { Casalnuovo, Caivano, Cardito, Crispano, } \\
\text { Frattaminore, Volla, Cercola) }\end{array}$ & $\begin{array}{l}519425(2017) \\
\bullet C \& D\end{array}$ & $\begin{array}{l}- \text { OW } \\
\text { - Wastescapes }\end{array}$ \\
\hline $\begin{array}{l}\text { Ghent-Belgium } \\
\text { (Ghent-Destelbergen) }\end{array}$ & $\begin{array}{l}277065(2017) \\
\text { Ghent } 259.083 \\
\text { Destelbergen } 17.982\end{array}$ & - OW from households and SME \\
\hline $\begin{array}{l}\text { Hamburg-Germany } \\
\text { (Bezirk Altona and Kreis Pinneberg) }\end{array}$ & $\begin{array}{l}577734(2016) \\
\text { Altona } 270263 \\
\text { Pinneberg } 307471\end{array}$ & $\begin{array}{l}\text { - OW from households and } \\
\text { tree nurseries }\end{array}$ \\
\hline $\begin{array}{l}\text { Łódź-Poland } \\
\text { (Łódź, Nowosolna, Głowno, Stryków, } \\
\text { Brzeziny, Dmosin, Jeżów and Rogów) }\end{array}$ & $\begin{array}{l}757990 \text { (2017) } \\
\text { Łódź itself } 690422 \text { (2017) }\end{array}$ & $\begin{array}{l}\text { - Municipal solid waste -especially } \\
\text { OW fraction }\end{array}$ \\
\hline $\begin{array}{l}\text { Pécs-Hungary } \\
\text { (Pécs and } 41 \text { municipalities) }\end{array}$ & $\begin{array}{l}144188 \text { (2017) } \\
\text { Pécs agglomeration } \\
179719(2017)\end{array}$ & $\begin{array}{l}\text { - OW } \\
\text { - Plastic packaging waste } \\
\text { - Residual waste } \\
\text { - Wastescapes }\end{array}$ \\
\hline
\end{tabular}

omy towards one based on the principles of the CE by 2050 (Ministry of Infrastructure and Environment \& Ministry of Economic Affairs, 2016). In addition, the national government has formulated specific CE policies focusing on specific sectors, for instance construction (Rijkswaterstaat \& Ministry of Infrastructure and Environment, 2015).

The Amsterdam Metropolitan Area (AMA) can be regarded as one of the frontrunners in moving towards a CE. The AMA spans across the boundaries of two provinces and encompasses the city of Amsterdam and 32 municipalities. For instance, the city of Amsterdam has formulated a circular city policy, which gives direction to public and private decision-making in the metropolitan area (Municipality of Amsterdam, 2016), and the municipality of Haarlemmermeer has the ambition for a transition towards a regional circular society and economy (Bosch, 2015). Moreover, various private actors, including waste management companies, as well as construction companies working on circular development initiatives, formulate their own ambitions.

Some of the key CE objectives for the AMA include: (1) redeveloping the Amsterdam docklands and wastescapes while limiting the amount of construction and demolition waste; (2) reusing the airport wastescapes surrounding, and reducing the food waste from Schiphol airport; and (3) reducing and reusing biowaste from agricultural production in greenhouses and flower trading within the Greenport Aalsmeer area.
Stakeholders identified a variety of specific challenges for reaching the above objectives, including: (1) conflicting interests of stakeholders across and within organizations; (2) lack of awareness of CE solutions and business models, particularly among the business players; (3) organizational fragmentation and lack of regional leadership; and (4) regulatory, financial and behavioral obstacles to learning from and upscaling circular innovations. Both the area-specific, waste-specific, and governance-specific challenges result in ambiguous and complex governance settings in which to promote a CE strategy in the AMA.

\subsection{Naples}

In Italy integrated waste management started in 2006. Being recent, this measure has been absorbed differently by regional policies, and this is truly evident in southern Italy. In particular, the Campania region has experienced two environmental crises since the mid-nineties, whose effects are still ongoing: the Waste Emergency and the Land of Fires. Both crises arose from government incapacity and the poor governance model in use (REPAiR, $2017 d$ ). As a consequence of the socio-ecological decay process, the abandonment and illegal deposit of waste along peri-urban streets and infrastructure has contributed to the proliferation of wastelands. In the case-study area, which extends towards the North-East of Naples up to the town of Acerra, the assemblage of dif- 
ferent kinds of wastelands has consequently given shape to wastescapes (REPAiR, 2017a).

What local authorities have to aim at is a multi-level governance through which the CE approach can be applied to both the waste management and the wasteland regeneration (Berruti \& Palestino, 2019). In order to achieve this objective, there are some key challenges to face:

(1) the stalemate in the waste management system, for which institutions do not care or even exploit at the different levels. The Regional Authority is playing its decisional power without calibrating rules to local contexts or turning them into effective policies; municipalities are interested in preserving benefits related to the previous waste system and companies selected through political nepotism. Surprisingly, Metropolitan City of Naples has been wrongly excluded from the governance of waste management by the regional law;

(2) the increase of wastelands due to intrainstitutional difficulties in overcoming sectoral policies and conflicting powers;

(3) the lack of shared knowledge among institutions and towards citizens;

(4) suspicion, stigmatization and distrust making it difficult to innovate policies and develop new economies.

Promoting the relationship with communities through the co-design of places would be crucial for decisionmakers, in order to turn all the fragmented measures and rules into a pluralist strategic vision. It would be also crucial for institutions to sustain proposals coming from local stakeholders that otherwise risk failure.

\subsection{Ghent}

Flanders has a long history of Waste Management. Since 1981 a combination of instruments and tools has been used to move waste management further up in the waste hierarchy, promoting prevention and material recovery (REPAiR, 2017e). As a result, waste sensitivity is amongst the highest in Europe (REPAiR, 2017b).

The general legal framework for household waste management is determined at Flemish (regional) level, with implementation plans setting priorities, targets and general strategies. Customization at local (municipal) level remains possible, providing that waste management services are accessible to all.

The ongoing ambition to reduce the total amount of (residual) waste necessitates municipalities to look for eco-innovative solutions, in order to further improve resource management. While waste management has been integrated in the city's climate policy and urban planning, the shift to CE is yet to be made. Food waste prevention, local waste treatment and higher valorization of resources remain challenging.
In the case-study area, Vegetables, Fruit, Garden waste (VFG) still represents a considerable amount of the residual waste. Challenging collection conditions (smell, hygiene, volume) for households and waste agencies, label VFG as a difficult waste flow to treat. However, many aspects determine the direct/proactive involvement of households to the separate collection of VFG. Legal obligations and financial incentives are only part of the solution. More compact living forms, changing family units, demographic evolution and new mobility trends all impact waste behavior. They ask for other collection methods than the classic kerbside collection or the collection in recycling parks. The diverse urban fabric calls for a customized approach and cost-benefits must be taken into account to guarantee an accessible service to all. Furthermore, open public space is scarce in the inner city as well as in peri-urban areas, resulting in a strong competition between different policy objectives.

\subsection{Hamburg}

Germany is widely considered as a frontrunner in dealing with environmental problems (European Environmental Agency, 2009; Wilts, 2016). Since 2012, the Circular Economy Act (Kreislaufwirtschaftsgesetz) guides actions related to waste management issues. The fulfilment of its requirements is the task of the Federal States. However, the interpretation of national regulations might substantially differ between states (REPAiR, 2017e, p. 23). This situation is reflected in spatial planning issues: in Pinneberg County (Schleswig-Holstein), municipalities develop their own spatial plans according to the national strategies without any restriction from the county. Meanwhile in Hamburg, binding plans are drafted at county level (i.e., the districts), as for the District of Altona, revealing a concentration of powers at higher levels. This setting might hinder pursuing CE actions, which call for cooperation between the two different states.

Just as the systems in the two states are distinct, the challenges that are faced have two different aspects. In Hamburg's District of Altona around one third of the bio-waste generated is thrown in the bins for residual waste. This is due in some households to a lack of separate bio-waste bins available and in others to improper disposal behavior, despite the many incentives provided for correct separation (REPAiR, 2017e, p. 31). The residual waste is incinerated, leading to a loss of valuable resources. In the case of Pinneberg, the focus is on the tree nurseries business as this economic activity characterizes the county. The bio-waste that is generated in tree nurseries is often directly incinerated on site, causing emissions that annoy the neighbors. This has led to protests and, jointly with an always increasing housing market pressure, the tree nurseries are at risk of being replaced in order to build new apartments.

Barriers are also present inside each Federal State, between different stakeholders and, sometimes, even within the same institution. As a matter of fact, stakehold- 
ers have mentioned the necessity of a more integrated approach between planning and waste management to overcome these challenges and to reach more circularity.

\section{5. Łódź}

In Poland two regulations are currently in force: one on waste from 2012 (amended in 2015) and the Act of 1996 on maintaining cleanliness and order in municipalities (amended in 2011 and 2014). The authority responsible for organizing waste management is the municipality. Moreover, municipalities' responsibilities comprise ensuring the construction, maintenance and operation of waste treatment infrastructure as well as including all households in the municipal waste management system and providing selective waste collection. Municipal authorities appoint waste collection companies by means of public tender (REPAiR, 2017e).

After various meetings and interviews with local stakeholders, three key challenges related to waste management in Łódź Agglomeration were identified:

(1) Environmental awareness of inhabitantsconcerns inadequately low level of socioecological awareness, manifested mainly in improper or even lack of waste separation. As a consequence, the amount of waste to be recycled is relatively low;

(2) Legal status-the regulations in force do not ensure high quality of service concerning collection and management of municipal waste. The issue regards the restricted possibility of establishing local recycling centers and meeting requirements of complex environmental procedures in a short time. Establishment of commercial institutions intended for waste management by local authorities is also hampered;

(3) Local government policy-local governments cooperate poorly with each other in implementing objectives of environmental policies. There is a lack of widespread actions to pass on good practices. Local authorities do not stand for lobbying innovative ecological solutions.

The coming years will be decisive to the process of stabilizing the waste collection and management system. A significant role should be played by local selfgovernment associations, which articulate the need for changes and modernization of approaches towards waste management, including enacting legal regulations. However, the successful implementation of CE principles will depend to the greatest extent upon enhancing the environmental awareness of the local population.

\subsection{Pécs}

Although there have been many remarkable achievements in regard to decreasing waste generation and improving waste management infrastructure, Hungary lacks a visible political intention related to circularity both at national and local levels. Furthermore, there are only few voluntary CE initiatives and projects in the private sector. According to the OECD report for Hungary, a whole-government approach is needed to accelerate towards CE (OECD, 2018). However, starting in 2010, a very strong centralization process within the whole governmental area can be observed, accompanied by the degradation of the independent environmental management system (in all lower decision-making levels). This centralization has resulted in the unavailability of secondary raw materials in the local market for public waste management companies, which led to a weakening in their importance in waste management activities. Because of this, local stakeholders' interest has dropped. A lack of a real iterative process in planning and decision making further complicates matters.

The EU-financed new waste management infrastructure (built in 2016) of the urban region Pécs has caused path dependency in technology in use for the next 20-25 years. As a result of this investment there is door-todoor collection for many materials. However, there are some remaining challenges: the low density of selection islands (collection points) and the lack of solutions for special waste collection and treatment (e.g., discharge the asbestos from the demolition waste).

On the other side of the waste chain, household behavior and attitudes need major improvement. In this case, the challenges in the urban region of Pécs consist of high rate of selectively collectable materials wrongly put in the residual waste (bins); garden waste burning practice of the households (instead of composting); heating with waste in poor families (REPAiR, 2017e).

The generation of wastescapes is related to the main economic development trajectory of Pécs. The three main groups of challenges are the closed mining sites and their spoil-bank, the leftover military sites and the abandoned industrial areas.

\section{Comparing Cases}

\subsection{PESTEL-O Table}

In order to understand and compare the main governance challenges to $\mathrm{CE}$ among the six cases, Table 2 was constructed using the PESTEL-O method. The next two paragraphs draw out the key common points of the challenges and the discussion of the main findings, respectively.

\subsection{Comparison}

Similarities can be identified by drawing out the key findings from the table for each category. The rule of thumb used here is that a certain challenge must be present in at least two cases and only the most significant points will be discussed. 
Table 2. Governance challenges: Policy/politics.

\begin{tabular}{llllll}
\hline Amsterdam & Naples & Ghent & Pécs & tódź & Hamburg \\
\hline - Lack of & $\bullet$ Competition & $\bullet$ Long-term and & $\bullet$ Lack of real & $\bullet$ Not enough & - Lack of \\
consistency in & among & solid cooperation & participation of & horizontal & integration of \\
municipal & municipalities for & are difficult to & stakeholders & municipal & waste \\
sustainability & leadership on & built & $\bullet$ Lack of & cooperation & management and \\
policies & waste & $\bullet$ Integrate CE in & decentralization & - Difficult & urban planning \\
- Lack of regional & management & urban planning & of decision- & cooperation & between local \\
$\begin{array}{l}\text { CE policy } \\
\text { formulation and }\end{array}$ & - Lack of policies & policies & making & authorities and \\
coordination & problems beyond & $\bullet$ Balancing & & private sector & \\
- Silo-mentality & administrative & general & & & \\
within & boundaries & regulations with & & & \\
governments and & $\bullet$ Regional & solutions & & & \\
business & policies not & & & & \\
regarding CE & calibrated to local & & & & \\
& contexts & & & & \\
\hline
\end{tabular}

Table 3. Governance challenges: Economic/financial.

\begin{tabular}{|c|c|c|c|c|c|}
\hline Amsterdam & Naples & Ghent & Pécs & Łódź & Hamburg \\
\hline $\begin{array}{l}\text { - Banks reluctant } \\
\text { in financing CE } \\
\text { ventures } \\
\text { - Limited } \\
\text { awareness of } \\
\text { successful CE } \\
\text { business models } \\
\text { in resource } \\
\text { management and } \\
\text { planning projects }\end{array}$ & $\begin{array}{l}\text { - European waste } \\
\text { management } \\
\text { sanctions to be } \\
\text { paid } \\
\text { - Tendering not } \\
\text { respondent to CE } \\
\text { processes } \\
\text { - Highest waste } \\
\text { tax of Italy in the } \\
\text { Campania Region }\end{array}$ & $\begin{array}{l}\text { - Financing and } \\
\text { up-scaling CE } \\
\text { initiatives in a } \\
\text { linear economy } \\
\text { - Developing } \\
\text { circular business } \\
\text { model equally } \\
\text { sharing burdens } \\
\text { and benefits } \\
\text { - Dual waste } \\
\text { system (house- } \\
\text { holds/industrial) } \\
\text { hinders waste } \\
\text { management } \\
\text { optimization }\end{array}$ & $\begin{array}{l}\text { - Local service } \\
\text { fees not purposed } \\
\text { for refinancing } \\
\text { new sectoral } \\
\text { investments } \\
\text { - Recently } \\
\text { centralized } \\
\text { secondary raw } \\
\text { material market } \\
\text { inaccessible to } \\
\text { local service } \\
\text { providers } \\
\text { - Many } \\
\text { non-re-cultivated } \\
\text { wasted areas } \\
\text { needing major } \\
\text { investments }\end{array}$ & $\begin{array}{l}\text { - Slow market } \\
\text { development for } \\
\text { eco-innovative } \\
\text { solutions } \\
\text { - Lack of business } \\
\text { models to } \\
\text { improve waste } \\
\text { management } \\
\text { processes } \\
\text { - Difficult process } \\
\text { of applying for } \\
\text { additional funding } \\
\text { for developing } \\
\text { innovative } \\
\text { solutions }\end{array}$ & $\begin{array}{l}\text { - Incentives for } \\
\text { waste separation } \\
\text { not clear/high } \\
\text { enough }\end{array}$ \\
\hline
\end{tabular}

Table 4. Governance challenges: Social/behavioral.

\begin{tabular}{|c|c|c|c|c|c|}
\hline Amsterdam & Naples & Ghent & Pécs & Łódź & Hamburg \\
\hline $\begin{array}{l}\text { - Consumer } \\
\text { readiness to pay } \\
\text { premiums for } \\
\text { circular products } \\
\text { - Reliance on } \\
\text { business leaders } \\
\text { to make the CE } \\
\text { transition }\end{array}$ & $\begin{array}{l}\text { - Citizens' distrust } \\
\text { of institutions } \\
\text { - Suspicion of the } \\
\text { quality of organic } \\
\text { and C\&D waste } \\
\text { products } \\
\text { - NIMBY } \\
\text { Syndrome in local } \\
\text { communities }\end{array}$ & $\begin{array}{l}\text { - Engaging } \\
\text { households in } \\
\text { fighting food } \\
\text { waste } \\
\text { - Participation } \\
\text { (quantity and } \\
\text { quality) in } \\
\text { separate } \\
\text { collection } \\
\text { VFG-waste } \\
\text { - Citizen's } \\
\text { knowledge and } \\
\text { support for CE }\end{array}$ & $\begin{array}{l}\text { - Excessive } \\
\text { (mainly landfilled, } \\
\text { food, plastic } \\
\text { packaging) waste } \\
\text { - Residual and } \\
\text { garden waste } \\
\text { burning practice } \\
\text { of households }\end{array}$ & $\begin{array}{l}\text { - Limited } \\
\text { (ecological) } \\
\text { awareness } \\
\text { regarding waste } \\
\text { burning for } \\
\text { heating and waste } \\
\text { separation } \\
\text { advantages }\end{array}$ & $\begin{array}{l}\text { - Waste topic not } \\
\text { included } \\
\text { sufficiently in } \\
\text { school curricula } \\
\text { - Little interest in } \\
\text { waste from either } \\
\text { landlords or } \\
\text { tenants }\end{array}$ \\
\hline
\end{tabular}


Table 5. Governance challenges: Technological/infrastructure.

\begin{tabular}{|c|c|c|c|c|c|}
\hline Amsterdam & Naples & Ghent & Pécs & Łódź & Hamburg \\
\hline $\begin{array}{l}\text { - Limited } \\
\text { awareness of CE } \\
\text { product } \\
\text { development } \\
\text { among producers }\end{array}$ & $\begin{array}{l}\text { - High percentage } \\
\text { of organic waste } \\
\text { displacement in } \\
\text { Northern Italy's } \\
\text { waste treatment } \\
\text { plants } \\
\text { - Disposal of Eco } \\
\text { bales } \\
\text { - Lack of recycle } \\
\text { points in the } \\
\text { peri-urban area }\end{array}$ & $\begin{array}{l}\text { - Improve } \\
\text { valorisation of } \\
\text { food surpluses } \\
\text { from distribution } \\
\text { chain } \\
\text { - Nuisance } \\
\text { related to storage } \\
\text { and collection of } \\
\text { VFG-waste }\end{array}$ & $\begin{array}{l}\text { - Path } \\
\text { dependency of } \\
\text { waste } \\
\text { management } \\
\text { system and } \\
\text { planning practice } \\
\text { - Low density of } \\
\text { waste collection } \\
\text { points } \\
\text { - Insufficient } \\
\text { solutions for } \\
\text { special waste } \\
\text { collection and } \\
\text { treatment (i.e., } \\
\text { asbestos) }\end{array}$ & $\begin{array}{l}\text { - Small number of } \\
\text { companies with } \\
\text { innovative } \\
\text { potential } \\
\text { - Insufficient } \\
\text { waste separation } \\
\text { infrastructure } \\
\text { (incompatible } \\
\text { container size) } \\
\text { - Limited capacity } \\
\text { for bulky waste } \\
\text { storage and waste } \\
\text { containers in } \\
\text { public space }\end{array}$ & $\begin{array}{l}\text { - Persistency of } \\
\text { existing waste } \\
\text { technology } \\
\text { prevents } \\
\text { innovation } \\
\text { - Long distances } \\
\text { between waste } \\
\text { generation and } \\
\text { treatment }\end{array}$ \\
\hline
\end{tabular}

Table 6. Governance challenges: Environmental.

\begin{tabular}{llllll}
\hline Amsterdam & Naples & Ghent & Pécs & tódź & Hamburg \\
\hline - Presence of & - Abandonment & - Environmental & - Points for & - Enhancing the & - Bio-waste \\
polluted or & and illegal deposit & impact of waste & separated waste & efficiency of & potential not fully \\
noise-restricted & of waste along & transport & $\begin{array}{l}\text { collection } \\
\text { frequently }\end{array}$ & waste collection & used for biogas \\
peri-urban & peri-urban streets & & becoming wasted & management & production \\
wastescapes in & - Deposit of Eco & & areas (illegally & aiming at \\
port and airport & bales in & dumped litter & reduction of \\
areas & peri-urban areas & & near the separate & mixed waste \\
& by Campania & & collection bins) & - Locating new \\
& Region & & - No solutions for & waste treatment \\
& - Peri-urban & & PLA (polylactic & plants \\
& assemblages of & & acid) collection, & - Suburbanization \\
& wastelands & & treatment and & significantly \\
& & low level of & increases waste \\
& & distribution & management \\
\end{tabular}

In relation to policy/politics, key challenges in the various case studies refer to a lack of leadership regarding waste management, the difficulty in formulating integrated waste management and planning policies, and a lack of stakeholder participation and cooperation. The main economic-financial challenges are the lack of tested CE business models and the difficult financing of CE initiatives. Observed social-behavioral challenges include a limited awareness about and engagement of citizens in waste collection, separation and management. The shared technological-infrastructural challenges are insufficient physical space for the collection, storage, separation and recycling points for waste. From an environmental point of view the cases illustrate the existence of wastelands, illegal waste dumping, and unwanted waste burning practices. Legislative challenges are very much case- and context-specific and thus difficult to generalize arbitrarily. Finally, widespread organizational challenges found are knowledge asymmetry and lack of dialogue within (intra-institutional) and between (interinstitutional) organizations.

\subsection{Discussion}

After pointing out the similarities using the PESTEL-O, now the specificities of governance challenges for each case are highlighted. Though the AMA is one of the frontrunners in moving towards circularity, it lacks common regional strategies and actions in the public sector and coherent actions between the private sector and public institutions. In the metropolitan area of Naples, by contrast, CE works as a rhetorical argument that is rarely ap- 
Table 7. Governance challenges: Legal.

\begin{tabular}{|c|c|c|c|c|}
\hline Amsterdam & Naples & Pécs & Łódź & Hamburg \\
\hline $\begin{array}{l}\text { - Construction } \\
\text { tender } \\
\text { procedures not } \\
\text { adequately } \\
\text { adapting CE } \\
\text { principles } \\
\text { - Unclear } \\
\text { legislation on } \\
\text { waste ownership } \\
\text { - No tax } \\
\text { disincentives for } \\
\text { companies and } \\
\text { households } \\
\text { producing waste }\end{array}$ & $\begin{array}{l}\text { - Legal control by } \\
\text { EU on regional } \\
\text { waste } \\
\text { management } \\
\text { - Poor measures } \\
\text { for implementing } \\
\text { CE processes } \\
\text { - Redundancy of } \\
\text { authorizations for } \\
\text { implementing } \\
\text { waste plants }\end{array}$ & $\begin{array}{l}\text { - Lack of room to } \\
\text { maneuver for } \\
\text { local } \\
\text { (government) } \\
\text { stakeholders }\end{array}$ & $\begin{array}{l}\text { - Privatized } \\
\text { collection } \\
\text { - Disrespecting } \\
\text { environmental } \\
\text { protection and } \\
\text { waste } \\
\text { management } \\
\text { legislation } \\
\text { - Lack of a } \\
\text { well-functioning } \\
\text { effective flow } \\
\text { monitoring } \\
\text { system }\end{array}$ & $\begin{array}{l}\text { - Conflicts } \\
\text { between waste } \\
\text { management and } \\
\text { other uses in } \\
\text { public spaces }\end{array}$ \\
\hline
\end{tabular}

Table 8. Governance challenges: Organizational.

\begin{tabular}{|c|c|c|c|c|c|}
\hline Amsterdam & Naples & Ghent & Pécs & Łódź & Hamburg \\
\hline $\begin{array}{l}\text { - Lack of regional } \\
\text { CE platforms and } \\
\text { networks } \\
\text { - Risk-avoiding } \\
\text { attitude towards } \\
\text { CE initiatives in } \\
\text { municipalities } \\
\text { - Knowledge } \\
\text { fragmentation } \\
\text { within and } \\
\text { asymmetry } \\
\text { between } \\
\text { organisations } \\
\text { (intra- and } \\
\text { inter-institutional) }\end{array}$ & $\begin{array}{l}\text { - Slow transition } \\
\text { in regional waste } \\
\text { management } \\
\text { - Organised crime } \\
\text { interests in } \\
\text { maintaining } \\
\text { waste } \\
\text { management } \\
\text { status quo } \\
\text { - Lack of } \\
\text { inter-institutional } \\
\text { and } \\
\text { intra-institutional } \\
\text { integration in } \\
\text { environmental } \\
\text { policies }\end{array}$ & $\begin{array}{l}\text { - Knowledge } \\
\text { asymmetry } \\
\text { between } \\
\text { stakeholders }\end{array}$ & $\begin{array}{l}\text { - Insufficient } \\
\text { level/mode of } \\
\text { knowledge and } \\
\text { information } \\
\text { transfer }\end{array}$ & $\begin{array}{l}\text { - Focus on waste } \\
\text { recycling, less on } \\
\text { design, } \\
\text { prevention and } \\
\text { reuse } \\
\text { - Lack of reliable } \\
\text { simulations } \\
\text { regarding actual } \\
\text { needs for } \\
\text { providing waste } \\
\text { management } \\
\text { infrastructure }\end{array}$ & $\begin{array}{l}\text { - No (or limited) } \\
\text { dialogue between } \\
\text { different } \\
\text { stakeholders and } \\
\text { sectors }\end{array}$ \\
\hline
\end{tabular}

plied in policies, due to inefficacy of sectoral planning and difficulties in fostering urban metabolism. In Ghent the transition to CE is well advanced, now the focus of local debates is how to upscale and mainstream CE initiatives. As CE is still a relatively new phenomenon in Łódź, there is a lack of cooperation between public authorities especially municipalities as well as between the public sector and enterprises. Furthermore, the citizens' environmental awareness with regard to CE and waste management is not yet very advanced. The Pécs case shows a lack of political interest in circularity and like in Łódź there are only few CE initiatives coming from the civic society. This indifference is worsened by a centralized environmental management system that hinders local actors' involvement. In the Hamburg case, in Pinneberg County the challenge is how to involve the private sector (tree nurseries) in CE activities, while in Hamburg-
Altona it is to bridge the gap between urban planning and waste management. The six cases show that, despite being in different stages of shifting towards CE, all of them are facing challenges in the implementation of CE strategies in overcoming sectoral policies and fragmented decision levels.

\section{Conclusion}

The study examined the necessity of understanding governance challenges in order to support urban regions in successfully shifting towards CE. The broad spectrum of governance challenges has been illustrated based on the case study specific analysis and their categorization according to the PESTEL-O method. According to the three dimensions that were introduced in Section two the following major governance challenges could be high- 
lighted. First, with regard to multi-level governance the examined cases show that while ambitious initiatives for CE do exist in urban regions, the connections between these local and regional initiatives to policies on higher political and administrative levels are lacking. Second, concerning cross-sectoral governance within the public sector the examples from the six urban regions demonstrate a lack of connection of CE strategies with other policy fields especially spatial planning. Another major challenge is the often-missing horizontal cooperation between municipalities. Strategies and activities often remain local, not using the opportunity of promoting CE in larger regional scale. Third, regarding multi-actor or quadruple helix governance: while in some of the examined urban regions many entrepreneurial and civic society initiatives exist that lack coordination and support by the public sector; in other regions still only few activities from the economic sector and citizens can be observed and the public sector is mostly absent in promoting CE.

From a methodological point of view it should be stated that the use of the PESTEL-O method has its limitations. While it is useful for categorization purposes, there is a risk of neglecting the complexity of some of the challenges that cross more than one division.

Although the results of this study are limited due to the fact that the research only comprises qualitative studies in six cases, the need for further and deeper examination of CE implementation challenges in urban regions can be derived from the described findings. Urban planning has the potential to steer CE processes and has a cross-thematic and integrative character which suits the complexity of CE implementation. Further, as we have shown, CE strategies and activities must be further spatialized. The nature of this future role of spatial planning in the realization of CE demands further investigation.

As mentioned before, the presented outcomes derive from an ongoing project, and in future research each of the cases will be examined in-depth. This will allow for the development of more specific implications for policies.

\section{Acknowledgments}

The research presented here is financed by the $\mathrm{H} 2020$ REPAiR project (Grant agreement no. 688920). During the research, Viktor Varjú has received the Bolyai János Scholarship.

\section{Conflict of Interests}

The authors declare no conflict of interests.

\section{References}

Advanced Metropolitan Solutions. (2017). Urban living labs: A living lab way of working. Delft: Delft University of Technology.

Bartlett, L., \& Vavrus, F. (2017). Comparative case studies: An innovative approach. Nordic Journal of Compara- tive and International Education, 1(1), 5-17.

Berruti, G., \& Palestino M.F. (2019). Le aree-rifiuto come sfida dell'economia circolare. Un cantiere aperto nella regione urbana di Napoli [Wastelands as a challenge of the circular economy. An open construction site in the urban region of Naples]. Urbanistica Informazioni, 270, 26-31.

BiPRO. (2012). Screening of waste management performance of EU Member States. München: BiPRO. Retrieved from https://ec.europa.eu/environment/ waste/studies/pdf/Screening_report.pdf

Bosch, S. P. (2015). Transition to a regional circular society: The case of Haarlemmermeer. Utrecht: Utrecht University Faculty of Geosciences.

Camaren, P., \& Swilling, M. (2012). Sustainable resource efficient cities: Making it happen. Nairobi: United Nations Environment Programme.

Chávez, A., Kennedy, C., Chen, B., Chertow, M., Baynes, T., Chen, S., \& Bai, X. (2018). Understanding, implementing, and tracking urban metabolism is key to urban futures. In T. Elmqvist, X. Bai, N. Frantzeskaki, C. Griffith, D. Maddox, T. McPhearson, . . . M. Watkins (Eds.), Urban planet: Knowledge towards sustainable cities (pp. 68-91). Cambridge: Cambridge University Press.

Codagnone, C., \& Wimmer, M. A. (2007). Roadmapping eGovernment research: Visions and measures towards innovative governments in 2020. Clusone: MY Print Snc di Guerinoni Marco \& C.

Collier, D. (1993). The comparative method. In A. W. Finifter (Eds.), Political science: The state of the discipline II (pp. 105-119). Washington, DC: American Political Science Association.

Dewulf, A., Meijerink, S., \& Runhaar, H. (2015). Editorial: The governance of adaptation to climate change as a multi-level, multi-sector and multi-actor challenge: A European comparative perspective. Journal of Water and Climate Change, 6(1), 1-8.

Ehnert, F., Kern, F., Borgström, S., Gorissen, L., Maschmeyer, S., \& Egermann, M. (2018). Urban sustainability transitions in a context of multi-level governance: A comparison of four European states. Environmental Innovation and Societal Transitions, 26, 101-116.

Ellen MacArthur Foundation. (2013). Towards the circular economy: Economic and business rationale for an accelerated transition. Cowes: Ellen MacArthur Foundation.

European Commission, Directorate General for Regional Policy. (2011). Cities of tomorrow: Challenges, visions, ways forward. Luxembourg: Publications Office of the European Union.

European Environmental Agency. (2009). Diverting from landfill: Effectiveness of waste-management policies in the European Union (EEA Report no 7/2009). Luxembourg: Office for Official Publications of the European Communities.

European Spatial Planning Observation Network. (2019). 
CIRCTER-Circular economy and territorial consequences. Applied research (draft synthesis Report, version 09/01/2019). Luxembourg: ESPON.

European Union. (2017). Circular economy action plan: Environment. European Commission. Retrieved from http://ec.europa.eu/environment/circulareconomy/index_en.htm

Fozer, D., Sziraky, F. Z., Racz, L., Nagy, T., Tarjani, A. J., Toth, A. J., ... Mizsey, P. (2017). Life cycle, PESTLE and multi-criteria decision analysis of CCS process alternatives. Journal of Cleaner Production, 147, 75-85.

Franco, M. A. (2017). Circular economy at the micro level: A dynamic view of incumbents' struggles and challenges in the textile industry. Journal of Cleaner Production, 168, 833-845.

Geng, Y., \& Doberstein, B. (2008). Developing the circular economy in China: Challenges and opportunities for achieving 'leapfrog development'. International Journal of Sustainable Development \& World Ecology, 158(3), 231-239.

Ghisellini, P., Cialani, C., \& Ulgiati, S. (2016). A review on circular economy: The expected transition to a balanced interplay of environmental and economic systems. Journal of Cleaner Production, 14, 11-32.

Girardet, H. (2015). Creating regenerative cities. Oxford: Routledge.

Kaarbo, J., \& Beasley, R. K. (1999). A practical guide to the comparative case study method. Political Psychology, 20(2), 369-391.

Kennedy, C., Pincetl, S., \& Bunje, P. (2011). The study of urban metabolism and its applications to urban planning and design. Environmental Pollution, 159(8/9), 1965-1973.

Knieling, J., Jacuniak-Suda, M., \& Obersteg, A. (2017). Urban-rural partnerships and governance of periurban areas in a European perspective. Towards regenerative regions. In A. Coucci, M. Magoni, \& S. Menoni (Eds.), Peri-urban areas and food-energywater nexus (pp. 31-37). Milan: Springer International Publishing.

McKinsey Global Institute. (2016). Urban world: The global consumers to watch. New York, NY: McKinsey \& Company.

Mietzner, D., \& Reger, G. (2005). Advantages and disadvantages of scenario approaches for strategic foresight. International Journal of Technology Intelligence and Planning, 1(2), 220-239.

Milligan, B., \& O'Keeffe, M. (2019). Global governance of resources and implications for resource efficiency in Europe. Ecological Economics, 155, 46-58.

Ministry of Infrastructure and Environment, \& Ministry of Economic Affairs. (2016). A circular economy in the Netherlands by 2050: Government-wide programme for a circular economy. The Hague: Ministry of Infrastructure and the Environment and Ministry of Economic Affairs.

Municipality of Amsterdam. (2016). Circular Amsterdam: $A$ vision and action agenda for the city and metropoli- tan area. Amsterdam: Municipality of Amsterdam.

Nilsson, M., Eklund, M., \& Tyskeng, S. (2009). Environmental integration and policy implementation: Competing governance modes in waste management decision making. Environment and Planning C: Government and Policy, 27(1), 1-18.

OECD. (2018). OECD environmental performance reviews: Hungary 2018. Paris: OECD Publishing.

Osborne, S. P., \& Brown, K. A. (2005). Managing change and innovation in public service organizations (1st ed.). London: Routledge.

Petit-Boix, A., \& Leipold, S. (2018). Circular economy in cities: Reviewing how environmental research aligns with local practices. Journal of Cleaner Production, 195, 1270-1281.

Prendeville, S., Cherim, E., \& Bocken, N. (2018). Circular cities: Mapping six cities in transition. Environmental Innovation and Societal Transitions, 26, 171-194.

Reed, M. S., Graves, A., Dandy, N., Posthumus, H., Hubacek, K., Morris, J., . . . Stringer, L. C. (2009). Who's in and why? A typology of stakeholder analysis methods for natural resource management. Journal of Environmental Management, 90, 1933-1949.

REPAiR. (2017a). D3.1: Introduction to methodology for integrated spatial, material flow and social analyses (Project Report, final version). Delft: Delft University of Technology. Retrieved from http:// h2020repair.eu/wp-content/uploads/2018/03/ Deliverable_3.1_Introduction_to_methodology.pdf

REPAiR. (2017b). D3.2: Socio-cultural/socio-economic and company-related investigations for pilot cases. Pécs: MTA KRTK-Institute for Regional Studies. Retrieved from http://h2020repair.eu/wpcontent/uploads/2019/03/Deliverable-3.2-Socioculturalsocio-economic-and-company-relatedinvestigations-for-pilot-cases.pdf

REPAiR. (2017c). D5.1: PULLs handbook (Project Report, version 1.11). Delft: Delft University of Technology. Retrieved from http://h2020repair.eu/ wp-content/uploads/2017/09/Deliverable_5.1_ PULLs_Handbook.pdf

REPAiR. (2017d). D6.1: Governance and decision-making processes in pilot cases (Project Report, version 1.6) Hamburg: HafenCity, University Hamburg. Retrieved from http://h2020repair.eu/wp-content/uploads/ 2017/09/Deliverable_6.1_Governance_and_ Decision-Making_Processes_in_Pilot_Cases.pdf

REPAiR. (2017e). D6.2: Governance and decision-making processes in follow-up cases (Project Report, version 1). Hamburg: HafenCity University Hamburg. Retrieved from http://h2020repair.eu/wp-content/ uploads/2019/03/Deliverable-6.2-Governance-andDecision-Making-Processes-in-Follow-up-Cases.pdf

Rijkswaterstaat, \& Ministry of Infrastructure and Environment. (2015). Circular economy and the Dutch construction sector: A perspective for the market and government. The Hague: Rijkswaterstaat and the Ministry of Infrastructure and the Environment. 
Schmitt, P., \& van Well, L. (2016). Revisiting territorial governance. Twenty empirically informed components. In P. Schmitt \& L. Van Well (Eds.), Territorial governance across Europe. Pathways, practices and prospects (pp. 221-237). Oxford: Routledge.

Song, J., Sun, Y., \& Jin, L. (2017). PESTEL-analysis of the development of the waste-to-energy incineration industry in China. Renewable and Sustainable Energy Reviews, 80, 272-289.

Van Well, L., \& Schmitt, P. (2016). Territorial governance across Europe. Setting the stage. In P. Schmitt \& L. van Well (Eds.), Territorial governance across Europe. Pathways, practices and prospects (pp. 3-20). Ox- ford: Routledge.

Williams, J. (2019). Circular cities. Urban Studies Limited Journal. Advanced online publication. https:// doi.org/10.1177/0042098018806133

Wilts, H. (2016). Germany on the road to a circular economy? Bonn: Division for Economic and Social Policy of the Friedrich-Ebert-Stiftung.

Yin, R. K. (2009). Case study research. Design and methods (5th ed.). Thousand Oaks, CA: SAGE Publications. (Original work published 1984).

Yüksel, I. (2012). Developing a multi-criteria decisionmaking model for PESTEL analysis. International Journal of Business \& Management, 7(24), 52-66.

\section{About the Authors}

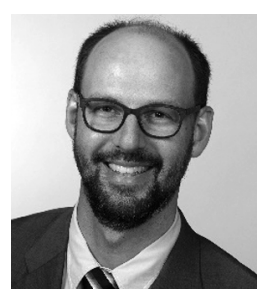

Andreas Obersteg (Dipl.-Geogr.) is Research Associate at the department of Urban Planning and Regional Development at HafenCity University Hamburg. He graduated in economic and social geography with minor subjects in spatial planning, regional development and business administration at TU Munich and University Tours (France). His research is comprised of several European projects on city-regional development and governance, urban-rural partnerships and circularity in city regions.

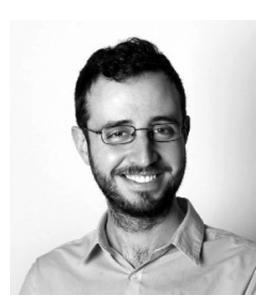

Alessandro Arlati (MSc) is Research Associate at the department of Urban Planning and Regional Development at HafenCity Universität Hamburg. His research and interests are in the field of multilevel governance, decision-making processes and circular economy and their effects on the spatial dimension.

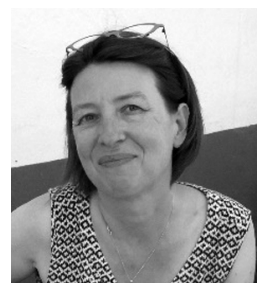

Arianne Acke has a master in diplomatic science and has been working for OVAM, the Public Waste Agency for Flanders, as part of the teams Policy Innovation and Construction, where she' been responsible for the follow-up of several European projects. She has a vast experience in international cooperation and educational projects, both with the public and private sector.

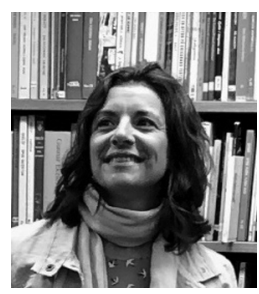

Gilda Berruti is Researcher in Town and Regional Planning at the Department of Architecture, Federico II University of Naples (Italy). Her research interests include public spaces between urban form and social dimension, inclusive urban policies and plans, the sustainable city as an aspect of the new urban question. At present, she is focusing on the relationship between planning rules and urban informalities.

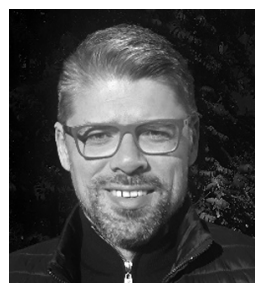

Konrad Czapiewski (PhD) has authored more than eighty scientific publications in areas of rurality, locality, regional periphery and spatial analysis and participated in ca. 50 international and domestic research and application projects including among others scientific projects for Horizon 2020 and ESPON. His research interests are in areas of rural geography, rural development, functions of rural areas, local development, human geography, human capital, knowledge transfer and endogenous growth. He is an Editor-in-Chief of journal Studia Obszarów Wiejskich/Rural Studies. 


\section{COGITATIO}
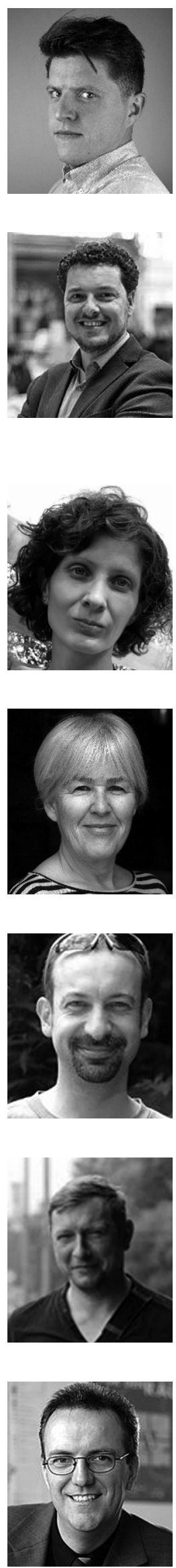

Marcin Dąbrowski (Dr) is an Assistant Professor at the Chair of Spatial Planning and Strategy in the Department of Urbanism, Faculty of Architecture and the Built Environment, Delft University of Technology, where he conducts research and teaches in the fields of spatial planning and territorial governance. He has a background in political science and regional studies, however, his research interests span across many topics related to governance of territory, from regional strategies for circular economy, or energy transition, to regional development policies, governance of urban climate change adaptation and the evolution of spatial planning systems in Europe.

Erwin Heurkens (PhD) is Assistant Professor in Urban Development Management at Delft University of Technology. Erwin holds master's degree in Real Estate \& Housing, and a PhD in Urban Development. His research expertise lies in 'sustainable private sector-led urban development projects', with a focus on public-private partnerships, real estate development, spatial planning, international comparative studies, and governance and decision-making. Erwin co-edited two international books on real estate development, published various articles connecting planning with real estate, participates in various international research projects, and conducts professional research for Dutch government agencies and market actors.

Cecília Mezei (PhD) is a Researcher at the Institute for Regional Studies of the Hungarian Academy of Sciences (MTA KRTK). She holds a PhD in Regional Studies and a master's degree in economics. Her main research areas are the local economic development theories and practice, the modelling of local resource-based development potentials and the adaptive waste management solutions. She is an associate professor at the Kaposvár University. ORCID: 0000-0003-2109-2293

Maria Federica Palestino is Associate Professor of Urban Planning at Federico II University of Naples, Italy. She belongs to the staff of the Architecture PhD School and she is member of the editorial board of the scientific Journal Crios, of which she is co-founder. Her primary research interest is the design of inclusive action-research processes aimed at the social construction of urban plans and programs. Her specific focus is on how to enhance local identities and public images through community participation and involvement. In her latest research project she is exploring the empowerment of fragile communities and places to recover from socio-ecological decline.

Viktor Varjú (PhD) is a Senior Research Fellow at the Institute for Regional Studies (MTA KRTK). He holds a PhD in Earth Sciences and master's degrees in geography and sociology. His main research areas are social aspects of regional development, renewable energy, circular economy and other environmental related topics. He has published in environmental sociology and environmental policy integration in regional and spatial development. ORCID: 0000-0003-3954-4518; Scopus ID: 54796211300

Marcin Wójcik (PhD) is Professor at the University of Lodz, Faculty of Geographical Sciences, Department of Regional and Social Geography. He is the author of publications on rural development, cultural landscape, local development, and socio-spatial diversities, and manager of national and international projects. He is also the Chairman of the Commission of Rural Areas of the Polish Geographical Society, Member of the Lodz Scientific Society and the Task Force for Rural Areas of the Committee for Spatial Economy and Regional Planning (Polish Academy of Sciences).

Jörg Knieling holds the Chair of Urban Planning and Regional Development at HCU and is dean of the urban planning program at HCU. He is member of the German Academy for Spatial Research and Planning (ARL), of the advisory board for spatial development of the German Ministry of Transport and digital Infrastructure. His main research fields are sustainable urban and regional development, spatial development and climate change, and related aspects of territorial governance and planning theory. He has conducted several international and national research projects in recent years, current publications have been on Soft Spaces in Europe (2015), Climate Adaptation Governance (2013), and Planning Cultures in Europe (2009). He has been referee for European Commission (DG Research), the European Institute of Technology (EIT), and a number of national research councils. 